\title{
Economic Globalization And Women's Employment: Study Of Industrial Sector Of Karachi
}

\author{
Shagufta Nasreen \\ \& \\ Nasreen Aslam Shah \\ Women's Studies \\ University of Karachi
}

\begin{abstract}
Globalization is a term which has different meanings for different people and the reason is its multidimensional connection with economic, political, social, cultural, environmental and many other aspects shaping the lives of people around the world. Although it has vast meaning but one of its important aspects is economic this has appeared to be the major factor of influence for its other dimensions as well. This study explores the impacts of these policies on women working in industrial sector of Karachi. The impacts are not on employment but their health, safety, working conditions and decision making. It shows that formal jobs for women was already low and informal, contract based jobs are increasing. In some sectors more women are hired because of their perceived docile, tolerant and satisfied with substandard wages. Majority of women are hired in garments. Analysis of secondary data from the year 1990-2009 shows that the perceived idea of growth, increase in employment and development was not successful. Economic globalization in the form of economic policies of trade liberalization, privatization and fiscal austerity could not improve the macroeconomic indicators of Pakistan thereby increasing burden on poor, salaried class and women.
\end{abstract}

\section{تلخيصِ مقالْ}

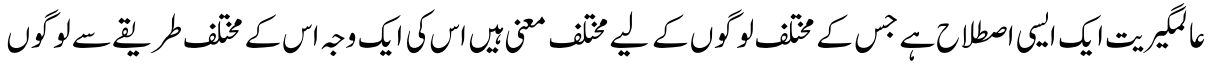

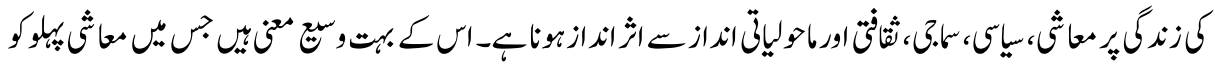

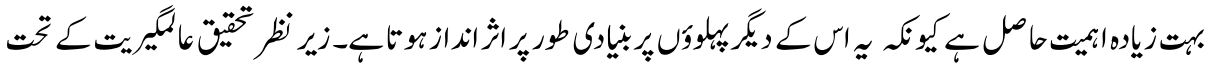

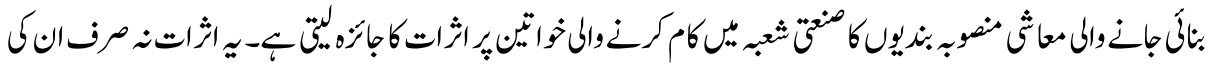

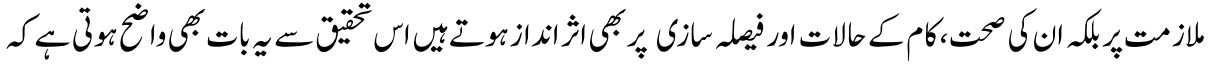

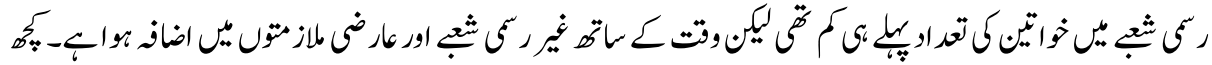

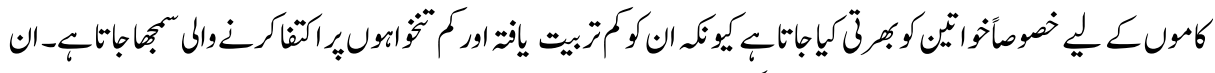

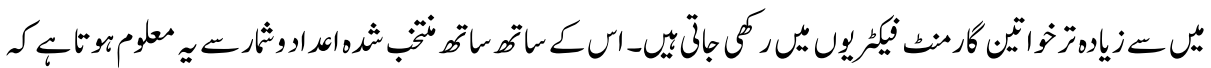

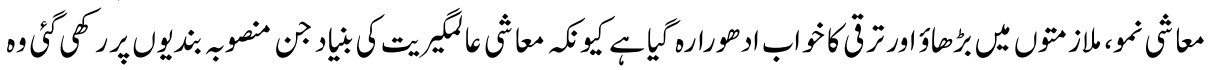

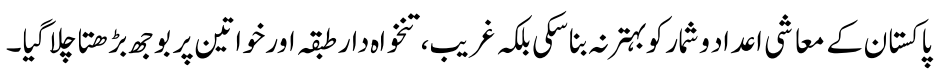




\section{Introduction}

Globalisation is neither a modern concept nor its strategies emerge out of to-day's technological advancement. Knowledge about the existence of the others was there in almost all civilizations now laid bare to us through archaeological explorations. How the Sumerians, Babylonians, Egyptians, and the people of the Indus Valley exchanged goods and ideas with each other and how they excelled in creating equipments and means for narrowing geographic distances marvels one living now in the age of the satellites. Thus, globalisation, though is a cross-border movement and activity, and yet in its genesis it is local.

Globalization has no a single definition; it is defined in a variety of ways. It is often referred to as increasing integration of economies, sometimes to the movement of people (labour) and knowledge (technology) across international borders (Stiglitz, 2002). Friedman (2000) explain it as inexorable integration of markets, nation states and technologies, enabling individuals, corporations and nation states to reach around the world farther, faster, deeper and cheaper than ever before. Kingsbury (2008) drawing upon various authors and sources concludes that it is a process or series of linked processes leading to greater interaction and integration. Chow (2002) similarly defines that globalization refers to the compression of the world in spatial and temporal terms, describing the ever-changing and intensifying networks of cross border consciousness, human interaction, system interdependence and transformation on a world scale. Anthony Giddens (1990) explains that globalization is the intensification of worldwide social relations through time /space destination. It is multifaceted concept that encompasses a variety of meanings and dimensions (Giddens, 1990). Arjun Appadurai (1990) suggest that current global flows occur in and through the growing integration and disjuncture of different landscapes-finanscpaes (e.g. money and trade) technoscapes (e.g. technology and information) ethnoscapes (e.g. people through international migration and travel) medias capes (e.g. mass media and communication) and ideoscapes (e.g. ideas, images and ideology) (Appadurai, 1990). Used for the first time in the 60's in the context of the establishment of transnational corporations, the term however gained wider usage by mid 80 s. Thus, globalisation initially was a term first used in the context of trade and economy.

Towards the end of Second World War, four international institutions of major historical proportions were founded. They were an integral part of the political and economic settlement arising from the long global conflict. These were, the World Bank, the International Monetary Fund (IMF), the General Agreement on Tariffs and Trade(GATT) and the United Nations (UN). These institutions are considered to play a major role in the process called 'economic globalization'. The process was triggered when GATT was reviewed in 1995. Out of the negotiations another organization known as WTO (World Trade Organization) was created out of 125 member states in Uruguay Round. WTO is 
the world's main International organization to promote order and cooperation in world trade and as such the world's main organization operating it.

There are different ideas about globalization. For some it is a process and the world system in which countries were pushed into giving benefits to some and creating problems for others. For others it is being very successful and there is substantial evidence, from countries of different sizes and different regions that when countries "globalize" their citizens' benefit, in the form of access to a wider variety of goods and services, lower prices, more and better-paying jobs, improved health, and higher overall living standards. According to IMF it is probably no mere coincidence that over the past 20 years, as a number of countries have become more open to global economic forces, the percentage of the developing world living in extreme poverty-defined as living on less than $\$ 1$ per day-has been cut in half. ${ }^{1}$ However, critics' of globalisation state that the notion of free trade based on comparative advantage woks primarily to the benefit of industrialized countries that can take advantage of cheap labour and good produced in developing countries. Kingsbury (2008) cites IMF itself recognizing that it has not relived a large part of populations especially in Sub Sahara Africa, which has increased the gap between rich and poor countries (Kingsbury, 2008, p. 98).

The concept of globalization is very much linked to the definition of development. The concept of development has its historical and intellectual roots in the period of major social changes associated with Industrial Revolution. It was defined in terms of more "modern", technological and economically 'advanced' forms of society. Initially development policies stressed the importance of expanding production and modernize the physical and social institutions (Kuper, 1985, p. 198). It was earlier and even today measured in economic terms by gross national product (GNP) and is considered to show the level of 'development'. The World Bank uses GNP per capita to classify economies as "low income", "middle income" or "high income". This concept was later redefined by neo-Marxist and dependency theorist by arguing that development means more than economic expansion, industrial productivity and income. Feminist scholars and practitioners further expanded the meaning of development to encompass improvements in human well being and in the ability of people to achieve their potential, self determination and empowerment (Chow \& Lyter, 2002, p. 26). Therefore it is necessary to take a holistic approach to understand the impact of globalization on gender roles and employment.

Employment is an important indicator of human development. It shows increase over period of time but the percentage of women in employment is low if we compare with the population growth rate and economic growth rate. They are largely seen in informal sector and face disparity both in terms of employment conditions and wages in formal sector as well. Traditional development economists and modernization theorists have viewed economic development as process in which economic growth and women's 
incorporation into the labour force go hand in hand. Others however argue that the process of industrialization and economic development is accompanied by marginalization of women (Bhattacharya, 2007).

Feminist scholars and researchers have contributed a lot in analysis and redefining 'work', development and impact of economic policies on women. Women constitute half of the world population and are majority of the world poor bearing triple burden of unpaid household work, low wage market and community activities. Rege maps three overlapping perspectives of feminist studies about globalization. She categorizes them as the first, gender and political economy of the development perspective focusing the Structural Adjustment Programs (SAP) in South Asia, Africa and Latin America. The second transnational feminist perspective draws upon postcolonial analyses of uneven and dissimilar circuits of culture and capital. The third perspective draws upon women experiences living through the post communist transitions. She further states that feminist analysis has sought to unmask the gendered character of the neo-liberal discourse. Deregulation has been accompanied by an increased regulation of reproduction, austerity by consumerism and a feminised workforce with increased level of malnutrition and violence against women. Analyses of women's labour bring into focus the four areas of labour generally overlooked: subsistence, unpaid work, domestic production and voluntary work. She suggest at this point that only differences between men and women should not be analyzed rather including complex relations of power in different class, caste, and ethnic locations. Mies (1998) pointed out coercive job losses of women in developed countries and creation of low paid jobs for women in developing countries by capitalism. At present the number of women in paid jobs has increased but we need to understand the quality of this change. Afshar and Berrintos explain that women of the world are being effected by globalization and 'the effects have been multiple and contradictory, inclusionary and exclusionary'. They identify its main features increasing economic liberalization, free trade and more deregulated labour, goods and financial markets and dominance of Transnational Corporations (TNCs) (Afshar \& Barrientos, 1999). Momsen(2004) analyze that due to globalization integration has occurred between countries and people and it has been utilized by TNCs. Susan Horton observes changes in employment patterns after globalization. It has become urban centred, industries have changed as well as occupations and the wage gap between men and women has reduced due to increase in women education and experience. But at the same time she notes some exploitation especially for those who have migrated from rural areas. In the process of globalization gradually the state control over resources declines and corporations capture the markets which usually lead to suppression of union organization and degradation of environment. Koggel (2003) analyze the increase labour force participation of women and its linkage to freedom and choices. Women's freedom and agency are not always improved when they enter the work force so the need is to take 'Informed discussion of development processes and policies must include accounts of global forces of power and 
their intersection with and utilization of local systems of oppression. Fussell (2000) explore another aspect that MNCs exploit the women workers of third world countries because of absence or ineffectual labour laws.

This study examines the impact of economic globalization on Pakistan economy and in turn its effects on women working in industries of Karachi. Pakistan is a developing country. Statistics shows that it lags behind other South Asian countries in terms of human development. According to the Human Development Report 2011, Human Development Index (HDI) rank for Pakistan is 125. Adult literacy rate in Pakistan is 54.2 percent. Out of the total population of 184753.3, 22.95 percent people live on less than PPP US \$ 1.25 per day. Earlier in 2009 Human Development Report stated that female economic activity rate for ages 15 and above is $36.3 \%$ and the percentage varies in different sector, highest in agriculture and lowest in industry. However, women political participation has shown marked increase with $21 \%$ seats in parliament and Gender Empowerment Measure (GEM) ${ }^{2}$ rank was 99 (Human Development Report, 2009). All these measures need to be analyzed in context of globalization. As discussed earlier the development being carried out by integration of economies is showing imbalances in the world. The imbalances can be identified by the fact that different countries claim that their growth rate has increased but that "growth" is not reflected in the development of other indicators.

Pakistan Economic Survey, 2006-07 claimed that with open market policies and restructuring of economy Pakistan real GDP grew at an average rate 7.0 percent per annum. When we analyze the social indicators then the situation is not as expected. Along with other social indicator one indicator showing growing disparity is gender equality and social justice. Huge gaps in gender equality in the areas of women's education, health, economic empowerment, agriculture, fisheries and forestry were reported in Pakistan Country Gender Profile, (SDPI,2008,p.21).

In Pakistan the process of globalization started along with other developing countries. Analysts observe shift of policies from 1988 and 1990 when Pakistan signed agreements with IMF, World Bank and Asian Development Bank (Irfan 2008, Sayeed, 2001,Zaidi,1999). Irfan (2008) argue that shift in policies of the development sector squeezed its expenditure, compounded by the occasional erratic weather conditions adversely affecting the growth in agriculture, the major sector of the economy. The conjunctive influence of tariff rationalization, financial sector reform and privatization led to closure of factories and downsizing which in turn resulted into substantial job losses. The state ceased to be the employer of the last resort rather assumed the role of the auctioneer wherein a number of the public sector units were disinvested and sold to the private sector having adverse implication for employment generation. It may be added that poverty related expenditure of the government drastically reduced as a percentage of GDP during the decade of 1990s till 2003 thereby crucifying the poor at the altar of 
macro stabilization (Irfan, 2008). Kemal (1999) summarize from his findings that privatization has not been able to reduce the fiscal deficit. Qamar Abbas and Unsa Hussain review another aspect of privatization process which is deunionization. They argue that labour unions in Pakistan represent only $2.5 \%$ of the labour force of Pakistan and privatization has lead to further decrease in it (Abbas \& Hussain, 2008).

Various studies show that simultaneously with the introduction of SAPs, especially the liberalization policies, poverty has increased in Pakistan (Kemal \& Amjad, 1997) (MHCHD,1999). Khattak and Sayeed (2000) point out that poverty in Pakistan has led to an increase in labor supply, especially of women who have never worked before. Pakistan Employment Trends 2009 illustrate that during the last decade women's labour force participation grew to a large extent in Pakistan. Majority of females are in agricultural sector with little or no economic security. The share of employment for females has increased from 69.9 to 71.1 percent in informal sector. Hisam's (2009) comparative study about female workers in Bangladesh and Pakistan shows an estimated 30 percent of workforce in textile consists of the females. Within this sector, women workers are concentrated in low paid, labour intensive, downstream production. Khattak (2001) find that the sexual division of labour has by and large not changed due to increased participation of women in employment. The study shows that household responsibilities are shifted to other female members. Women are taking part in productive as well as reproductive 'responsibilities'.

Pakistan is a developing country and therefore it is important to study how globalization polices impact its economy. In this study, we are particularly interested in how it affects women. The number of women workers has increased in the industrial and service sectors as compared to the past but with deterioration in the working conditions. Globalization was expected to increase trade and investment, growth of tourism, information-based technologies and export manufacturing, thereby increasing economic opportunities for women. On the other hand, economic globalization based on policies of liberalization, privatization and fiscal austerity has been known to induce unemployment, deterioration in real wages, labour lay off, cut backs in social spending including health and education.

\section{Methodology}

For this research industries from the three industrial areas of Karachi ${ }^{3}$ were selected ${ }^{4}$ SITE Karachi, SITE North Karachi and Korangi Industrial area. ${ }^{5}$ The first task was to identify the number of industries in which women are employed. From earlier studies it is noted that mostly women are employed in textile and food industries, and drugs and medicine industry (Hafeez, 1989). To identify the total number of industries of Karachi, concerned governmental departments namely Industries and Commerce Department, Government of Sind, Sindh Small Industries Corporation, Sindh Bureau of Statistics, Sindh Employees Social Security Institution (SESSI), Employers federation of Pakistan 
(EFP) and Sindh Technical Education \& Vocational Training Authority (STEVTA) were contacted. All of these departments have data about number of industries and workers in factories and industries of Karachi. During the process a problem come about that they do not have sex segregated data. During meetings they informed that garments and pharmaceuticals have more women workers and the ratio of male to female is $80-20$ percent in the workforce. However STEVTA employment exchange provided the data which supported this argument. After that the selection of industries was very difficult task. Direct contact with these industries revealed that they were not willing to share any information regarding workers and many of them refused to conduct interviews with women workers. So the process of selecting the industries was changed. In Karachi Non Governmental Organizations (NGOs) were contacted which are working with labour unions in these areas. With the help of contact persons the researcher was allowed to fill the questionnaires from women workers. Another strategy adopted was to contact the female women councillor of the area and with her reference women workers were contacted. For this study probability sampling technique was used because it was not possible to study entire population women workers in industries of Karachi. Total 200 women workers were interviewed from 13 garments industries located in different industrial areas of Karachi. With the help of prepared questionnaire women respondents were asked the questions which were recorded on the questionnaire itself in the presence of the respondents. Secondary analysis research method was used to study official data and recent reports of government to relate the employment with selected macroeconomic indicators in the period of 1980- 2008. The raw data obtained from the questionnaire filled by the respondents was converted into statistical form of tables and graphs.

\section{Results and Discussion}

\section{Industries of Karachi}

According to the monthly survey of industrial production and employment in Sindh, January 2011 they categorize the large scale industries in thirty broad categories. It identifies increased gas prices, power and gas shortage of supply, increase in prices of cotton yarn and demand price cut from buyer have affected the production. It shows slight improvement $(0.43 \%)$ in employment as compared to December 2010 but it gives only total numbers. Sex disaggregated data is not available. According to the "Development Statistics of Sindh 2008" number of manufacturing establishments in Sindh was 1852 in the year 2005-06 with average daily employment 290,376. It is again in total with no distinction for male or females. Karachi has the highest number of establishments. In an informal interview, Deputy Director, Labour department, Sindh, in April 2011 informed that department conduct surveys in industries and manufacturing units to analyze the conditions of labour and the facilities they are provided. Total number of workers is 280822 by January 2011. In which he assumed that the ratio of 
male and female workers is 80 and 20 percent. According to him the data is incomplete and not provided by the industries.

\section{Female Employment in Industries}

The first objective of the research was to explore the industries in the urban industrial sector with high female labour force participation. Findings show that in Karachi the trend of female employment has not changed as such. The study of Sabiha Hafeez in 1989 showed the same industries as identified in 2009-2010 in which women are employed. These are mainly garments, pharmaceuticals, food and beverages. Another major finding regarding data of industries and number of workers was that they lack sex segregated data. For example The "Development Statistics of Sindh 2008" shows that number of manufacturing establishments in Sindh was 1852 in the year 2005-06 with average daily employment 290,376. It is in total with no distinction for male or females. To identify the number of industries in Karachi, those with high female employment and ratio of male and female workers became quite difficult. All the major sources such as Industries and Commerce department, Government of Sindh, Sindh Bureau of Statistics, EOBI, STEVTA and NILAT were visited to collect this data. They all had generalized data. During informal interviews and conversation they all agreed that the ratio of male and female is 80 and 20 percent as workers in industries. The detailed information was provided by STEVTA. It showed that in heavy industry such as motor companies and Ghee industries there are no women workers because it is considered heavy work, require more skill and women are never tried for such work. In textile mills again the situation is that women if employed are in office jobs in manufacturing area women are not employed. Pharmaceuticals and garments were the main areas where women are employed and the ratio of workers there is fifty percent for both.

\section{Economic Globalization and Employment Conditions of Women}

The second objective was to study the impact of globalization policies on the employment and income of women workers. It was analyzed in different steps. First of all the working conditions of women in formal sector were identified through primary data. After that macro economic conditions of Pakistan was analyzed from secondary sources. In Pakistan people in general are not very much aware about trade liberalization policies. The women workers interviewed were unacquainted with the idea of it. The supervisors or employers showed positive response towards it and said that it creates new opportunities of employment so it is positive but they were not concerned with the conditions of work it creates. In this way the direct impact on the women workers was difficult to measure from primary data. The primary data explore and confirms the low status of working women in most of the cases. Women suffer additional constraints because their mobility is limited. They have less control over resources; have limited decision making power, less knowledge and awareness of their rights. Despite this 
depressive state the fact remains that most of women work and work hard. Result shows that majority of these women are living in rented houses and their income goes in paying off rents and daily food needs of the house. They were earning for survival and didn't want to complain to their employers because they don't want to lose jobs. The major demand from government was to reduce inflation, complain about high prices. It is clear from the findings that it is in this exploitative and oppressive frame work that women are dealing under neo liberal policies, where the cost of living is high. Another problem is that work is not available for male members of these women so they are taking burden of household. In some cases men were not willing to do jobs.

The employment here is not leading to women autonomy. As perceived by traditional theorists that women participation in paid jobs leads to increase in their decision making and empowerment is not supported by this study. They are doing this work to sustain their lives, support their family needs. Further it was proved that women are mostly engaged in low skilled jobs. Women are mostly found in urban industrial sector of Karachi in low skilled jobs. Karachi is the largest city of Pakistan and the main financial centre of the country. There are many benefits for the women living in Karachi for example transport accessibility, accessible educational institutions, not too much restrictions on women employment. But the discrimination is very much existent in the labour force participation.

Occupational health is another very important aspect of women and work. Most of the women complained about effect on their health. It has physical as well as psychological impacts. Usually they are in stitching and continuously doing this work causes back pain, head ache, eye sight problems. From field observation it was noted that in majority of work places the conditions were difficult with low lighting facility and uneasy seats.

"I usually feel stress and pain in my back and want to quit the job but I don't have a choice"

"When I go back home I get tired and feel pain in my legs because most of the time I stand to supervise the work"

Even an employer said that "Women come to work in factory in better condition but during their employment they seem to lose their health day by day." 


\section{Table 1}

Distribution of Respondents According to Psychological Effects of Work

\begin{tabular}{|l|c|c|}
\hline Psychological effects of work & Frequency & Percentage \\
\hline Tension & 77 & $38.50 \%$ \\
\hline Depression & 45 & $22.50 \%$ \\
\hline Fear of dropped from job & 51 & $25.50 \%$ \\
\hline Fear & 16 & $8.00 \%$ \\
\hline Tiredness & 11 & $5.50 \%$ \\
\hline Total & $\mathbf{2 0 0}$ & $\mathbf{1 0 0 \%}$ \\
\hline
\end{tabular}

All of the respondents shared they feel tension, depression, have fear of loosing job and are fatigued.

The impacts are not only on economic only but gender relations as well. Women role in the family has not changed yet she has to do her paid job. Women are considered responsible for doing household activities. They leave their children when they go for jobs because day care facilities are available on limited bases. The very important indicator of why women enter into paid job answers in the reason due to poverty.

Table 2

Distribution of Respondents According to Reasons of Doing Work

\begin{tabular}{|l|c|c|}
\hline Reasons of doing paid work ( Unmarried) & Frequency & Percentage \\
\hline Economic problems & 103 & $82.40 \%$ \\
\hline Domestic disputes & 02 & $1.60 \%$ \\
\hline Personal needs & 20 & $16.00 \%$ \\
\hline Total & 125 & $100 \%$ \\
\hline Reasons of doing paid work (Married) & & \\
\hline Economic problems & 40 & $63.00 \%$ \\
\hline Domestic needs & 02 & $3.00 \%$ \\
\hline Personal needs & 13 & $21.00 \%$ \\
\hline Widow & 03 & $5.00 \%$ \\
\hline Divorcee & 05 & $8.00 \%$ \\
\hline Total & $\mathbf{6 3}$ & $\mathbf{1 0 0 \%}$ \\
\hline
\end{tabular}

The other reasons such as for fulfilment of self, empowerment or to utilize education is not the motive of work behind these women workers. Unionization is also very low in these workers. This also confirms the study of Hisam (2009) that trade unions are decreased or if present majority are males. The result also shows that mostly these women are young unmarried. They want to get married but due to financial problems of home their marriage is delayed. It also creates a feeling of incompleteness. This is not the 
case for these women workers. Highly educated, well paid young women also have the same feelings. The results of the study shows that in the industries women of young age (28-32 years) are working, unmarried, literate with not more than ten years of education. Majority of them have high number of dependents due to which more than one member is engage in income generation activities. Majority of them are earning below minimum wage level.

Table 3

Distribution of Respondents According to Personal Income of Women Workers on Monthly Basis

\begin{tabular}{|l|c|c|c|c|}
\hline $\begin{array}{l}\text { Personal income (monthly basis) } \\
\text { in Rs. }\end{array}$ & Frequency & \multicolumn{2}{|c|}{ Percentage } \\
\hline \multirow{3}{*}{$\begin{array}{l}\text { Below } \\
\text { Minimum } \\
\text { wage }\end{array}$} & Less than 1500 & 7 & $3.50 \%$ & \\
\cline { 2 - 4 } & $1500-3000$ & 20 & $10.00 \%$ & \multirow{3}{*}{$61.5 \%$} \\
\cline { 2 - 4 } & $3001-4500$ & 31 & $15.50 \%$ & \\
\cline { 2 - 4 } $\begin{array}{l}\text { Above } \\
\text { Minimum } \\
\text { wage }\end{array}$ & $4501-6000$ & 65 & $32.50 \%$ & \\
\cline { 2 - 4 } & $6001-7500$ & 43 & $21.50 \%$ & \multirow{3}{*}{$38.5 \%$} \\
\cline { 2 - 4 } & $7501-9000$ & 14 & $7.00 \%$ & \\
\cline { 2 - 4 } Total & $9001-10500$ & 15 & $7.50 \%$ & $\mathbf{1 0 0 \%}$ \\
\hline
\end{tabular}

They are doing paid job because to fulfil their economic needs of the household. Interestingly they were the first woman from their families to enter into paid jobs. Majority of them are spending their income at home. They are working for eight hours per day. They are not satisfied with their wages and nearly half of them do over time to increase their income. Their wages are equal to males. They are working in an environment where in most cases there are females and in some there are males co workers. They are satisfied with the working environment. They are in favour of women's paid employment. But they are unaware about labour laws and their implementation however they were about minimum wages and were receiving it. As expected and revealed by other studies that women are mostly in hosiery, readymade garments, bed sheets and towel industry. Males are in ginning, spinning and weaving. Women are mostly in stitching work. In textiles and garments 90 percent are on contract bases.

The study identified most of the women work to help their families in their economic disparities. However the general impression of the society is to the contrary. Women suffer from some of the assumptions and prejudices which males have towards them. The management feel that women are not serious or efficient workers. They put in less work and com only to pass time. As soon as they get married they will go away. If they 
continue job after marriage they will demand leave for domestic reasons such as maternity leave, childcare, transfer of husbands, become in efficient. For many such reasons women are not preferred. Some management may think that women may spoil the strict atmosphere of the workplace. At the time of selection women face discrimination male colleagues stare, pass remarks, at her looks or usually think that because she is female she has been selected otherwise she doesn't have skill. If the young women mix freely with colleagues she is considered 'azaad' (care free) if she confines to work she is labelled arrogant. If the boss appreciates her efforts she is scandalized.

In the mean time they also realize that they also have an identity of their own. But there are too many expectations from her. There is also many situations where in urban areas working women problems aggravate with their multiple role expectations. Women have to perform role of a mother, a wife, a home maker, worker and a citizen. A women engaged in paid work also have to look after domestic work. This dual responsibility has overburdened working women, thereby leading to multidimensional problems. Where joint family exists she is expected to fulfil the demands of her role as a daughter in law. She has a much larger are of social interaction. So her informal work increases more if she is a part of voluntary associations. Due to her multiple roles she has no time to relax. Chronic fatigue, weakness, is some of the results of such high level stress. Some other factors related to job are monotonous work, poor ventilation, unfriendly working atmosphere and discrimination at work place. Although Karachi is considered a modern city but traditional attitudes and behaviours exist. Since her primary responsibility is considered home and children they require to work at home and outside the home. Mothers have to face quite a lot of problems if she is going for paid job she leaves her child with someone which means additional expenditure if it is a day care. Children also feel neglected she suffers from guilt and find torn between the two. Even they are doing house work and do not get help from their husbands or male members of the family.

The impact on the economy directly impact on women. With high prices more women are pushed into jobs. These jobs are not improving their standard of living but fulfilling their basic needs. That is the reason in this research it was identified that women decision making power has not changed. The reason being is the lack of acceptance for female income in the society for the social norms and customs as even though many households are being financially headed by females but not socially and politically as they do not have the decision making power in their hands and are usually put behind by male dominance. The perception of the researcher based on review of literature was that they would have gained in self-confidence due to an increase in mobility, decision making powers access to and control over money and other resources thus leading to changed power relation with men. As identified during interviews with activists as well, due to globalization policies the formal sector has not expanded. Even in formal sector the workers are not permanent. They are waiting for their confirmation letters. As stated in 
case studies they have been working from more than three years and according to the labour laws the probation period is three months.

\section{Economic Globalization and its Impacts}

Table 4 shows selected macroeconomic indicators from 1981-2009. The reason of taking this time period is to take a quick look at the before and after globalization macroeconomic condition. The change in economic policies was based on the idea of economic growth, openness of markets, improving efficiency of public institutions by privatization and reducing fiscal deficit. Macroeconomic indicators shows that economic conditions did not improve much.

Table 4

Key Macroeconomic Indicators: 1981-2009

\begin{tabular}{|c|c|c|c|c|c|c|c|c|}
\hline Years & GDP & $\begin{array}{c}\text { Current } \\
\text { Account } \\
\text { Deficit }\end{array}$ & $\begin{array}{c}\text { Inflation } \\
\text { (Consumer } \\
\text { Price Index) }\end{array}$ & $\begin{array}{l}\text { Budget } \\
\text { Deficit }\end{array}$ & $\begin{array}{c}\text { Public } \\
\text { Investment }\end{array}$ & \begin{tabular}{|c|} 
Total \\
Investment
\end{tabular} & \begin{tabular}{|c} 
Exports \\
(Goods and \\
Services)
\end{tabular} & $\begin{array}{c}\text { Foreign direct } \\
\text { Investment }\end{array}$ \\
\hline & $\begin{array}{l}\text { Growth \% } \\
\text { per annum }\end{array}$ & \% of GDP & $\begin{array}{l}\text { Growth \% } \\
\text { per annum }\end{array}$ & $\begin{array}{l}\% \text { of } \\
\text { GDP }\end{array}$ & $\%$ of GDP & $\begin{array}{l}\text { Growth \% } \\
\text { per annum }\end{array}$ & \begin{tabular}{|l|} 
Growth \% \\
per annum
\end{tabular} & $\begin{array}{l}\text { Net Inflows } \\
\text { (\% of GDP) }\end{array}$ \\
\hline 1981 & 6.4 & 4.3 & 12.0 & n.a. & 9.1 & 18.4 & 12.31 & 0.38463493 \\
\hline 1985 & 8.7 & 3.1 & 5.2 & n.a. & 8.9 & 17.99 & 10.42 & 0.421864139 \\
\hline 1990 & 4.6 & 4.51 & 12.7 & 7.18 & 8.58 & 19.52 & 15.53 & 0.612997637 \\
\hline 1995 & 4.1 & 4.5 & 13 & 6.46 & 6.4 & 17 & 16.70 & 1.19175194 \\
\hline 2000 & 3.9 & 2.13 & 3.6 & 4.1 & 4.63 & 16.97 & 13.44 & 0.416484258 \\
\hline 2005 & 9.0 & 3.1 & 12.2 & 4.3 & 4.07 & 21.95 & 15.68 & 2.008211679 \\
\hline 2009 & 4.1 & 2.0 & 17.9 & n.a. & n.a. & 18.9 & 12.84 & 1.473547967 \\
\hline
\end{tabular}

Sources:

1) Hand book of Statistics on Pakistan Economy, 2010, http://www.sbp.org.pk/ departments/stats/PakEconomy_HandBook/index.htm

2) Economic Survey of Pakistan (different years)

3) World Bank http://data.worldbank.org/country/pakistan

The results here shows that these polices couldn't make the change promised. GDP growth rates show ups and downs. There are other contributing factors such as weak economic policies, continuous changes of governments, natural disasters and law and order situation of Pakistan. Inflation has increased manifolds increasing the cost of daily use items. Often quoted by Pakistani economists and common people is the prices of diesel and petrol. In 1999 it was Rs.10.80 and in early 2010 the cost was high as Rs. 73 per litre. It directly effects on the rates of all items making life more difficult for salaried poverty stricken population.

One of the major objectives of globalization policies has been reduction of budget deficit. It has not been achieved yet. Different taxes have been operated such General sales tax (GST), which was initially rejected by the business community. ${ }^{6}$ The reason was that they didn't want to show their actual sales. This is one of the problems accepted by the 
economists that tax collection system has become in effective which result in fiscal deficits. ${ }^{3}$ To reduce fiscal deficits another measure was privatization of public institutions. But that was also not a successful scheme. It also resulted in negative results, one of the example quoted is privatization of KESC. ${ }^{8}$ It has been five years that it is privatized neither it has become efficient nor the quality of service has improved. Value added tax (VAT) was another tax highly resisted by all groups. ${ }^{9}$ unfortunately the trend seen in Pakistan is that most of the taxes are paid by salaried people. This leads to an imbalance reflected in the indicators. Although this is true in case of Pakistan that direct link between impact of globalization and development is very difficult to measure because there are some other major factors contributing in the poor condition of the economy namely law and order situation especially after 9/11, natural disasters earthquake in 2005 and floods in 2010, corruption and unstable political condition. But the fact remains that the choice of polices in such conditions is also very important. Economists suggest different ideas and plans to improve the economy but the government takes different paths because they have agreements with IMF and World Bank.

In conclusion the present day Pakistani society women roles are changing. This change is brought by many factors and globalization is one of it. Although the study is not showing a direct negative or positive impact on women but in reality women and to great extent people in general do not consider the intensity of the policies that are planned for them by governments or international institutions. For many their first priority has become the survival for which they accept all conditions of employment. Women in this case are more affected. In discharging her dual role at home and work place and to strike an optimal balance amongst them, her satisfaction level varies. They are victims of poverty that has a central role to join industries. They are concerned about bad working conditions, bad environment, and harassment but they have no choice rather than accepting it due to poverty. They are not usually active in unionization. Policy makers continue the policy of liberalization, austerity and privatization because they think it is the only way to improve the economy. But in this process they only count women in labour force participation rates. At the time of decision making or budgeting the priority is not gender bases but increase in GDP growth and other macroeconomic indicators.

\section{End Notes}

1. http://www.imf.org/external/np/exr/ib/2008/053008.htm Rretrieved August 18, 2010

2. Pakistan is signatory some of the major International commitments such as Millennium development Goals (MDG) and Convention on Elimination of All Forms of Discrimination Against Women (CEDAW) to ensure social equity and justice. Pakistan has taken some major initiatives in this regard for poverty reduction namely Gender Reform Action Plan (GRAP) and Gender Support programme (GSP) 20032012. 
3. Karachi has an projected population of 15 million, which is at present growing at about 5\% per year, mainly because of rural-urban internal migration.( For details see City District Government Karachi, http://www.karachicity.gov.pk/).

4. Karachi accounts for the majority share of national GDP and revenue. Seventy percent $(70 \%)$ of income tax and $62 \%$ of sales tax collected by the Government of Pakistan comes from Sindh Province and of this $94 \%$ is generated in Karachi, while it produces about 42 percent of value added in large scale manufacturing. In its formal sector, the city has 4,500 industrial units. However, there are no estimates available for the informal sector. For details see (Hasan, 2003)For details visit http://www.findpk.com/yp/Biz_Guide/html/industrial_zones_sindh.html

5. For details visit http://www.findpk.com/yp/Biz_Guide/html/industrial_zones sindh.html

6. See for example this news report about protest against GST in 1998 http://www.gapcpakistan.com/G.S.T\%20in\%20Pakistan.php

7. http://dailymailnews.com/0910/29/Business/index.php?id=4

8. http://www.dailytimes.com.pk/default.asp?page=story 23-8-2005 pg5 1

9. http://www.dailytimes.com.pk/default.asp?page $=2010 \% 5 \mathrm{C} 05 \% 5 \mathrm{C} 14 \% 5 \mathrm{Cstory} 14-5$ $2010 \_$pg $5 \_8$

\section{References}

Abbas, Q., \& Hussain, U. (2008). Globalization, Privitization and Collective Bargaining of Labour : A Time Series Analysis of Pakistan 1973- 2004. 8th Global conference on Business and Economics. Florence.

Afshar, H., \& Barrientos, S. (1999). Women, Globalization and Fragmentation in the Developing World. London: Women Studies at York.

Appadurai, A. (1990). Disjuncture and Differences in the Global Cultural Economy. In M. Featherstone (Ed.), Global Culture: Nationalism, Globalization and Modernity (pp. 295-310). Newbury park, , CA: Sage.

Bhattacharya, R. (2007). Gender and Employemnt in the Context of Globalization: Some Facts and Figures. In R. Ghadially (Ed.), Urban Women in Contemporary India. India: Sage. 
Chow, E. N. (2002). Globalization, East Asian Development, and Gender : A historical Perspective. In E. N. Chow (Ed.), Transforming Gender and Development in East Asia. New York: Routledge.

Chow, E., \& Lyter, D. (2002). Studying Development With A Gender Perspective: From Main stream Theories to Alternative Frame Works. In E. Chow (Ed.), Transforming Gender and Development in East Asia (pp. 25-30). New York: Routledge.

Friedman, T. (2000). The Lexus and The Olive Tree. Anchor Books.

Fussell, E. (2000). Making Labor Flexible: The Recomposition of Tijuana's. Feminist Economics 6(3), 59-79.

Giddens, A. (1990). The Consequences of Modernity. Cambridge: Polity Press.

GOP. (2007). Economic Survey, 2006-07. Retrieved March 20, 2011, from Department of Finance: http://www.finance.gov.pk/survey_0607.html

Hafeez, S. (1989). Women in Industry in Pakistan-Vol I. Goverment of Pakistan, Women's Division, ( Cabinet secretariat), Islamabad.

Hisam, Z. (2009). Organizing for Labour Rights: Women Workers in Textile/ Ready made Garments Sector in Pakistan and Bangladesh. Karachi: PILER \& SAAPE.

Horton, S. (1996). Women and Industralization in Asia. New York: Routledge.

Human Development Report. (2009). Retrieved from UNDP: http://hdrstats.undp.org/ en/countries/data_sheets/cty_ds_PAK.html

Human Development Report 2011. (n.d.). Retrieved from UNDP.

Irfan, M. (2008). Pakistan's Wage Structure, During 1990/91 - 2006/07. Retrieved March 13, 2011, from PIDE: http://www.pide.org.pk/pdf/pws.pdf

Kemal. (1999). Privatization in South Asia: Minimizing Social Effects Through Restructuring. (G. Joshi, Ed.) Retrieved April 19, 2011, from ILO Publications: http://www.ilo.org/public/english/region/asro/bangkok/paper/privatize/index.htm

Kemal, A., \& Amjad, R. (1997). Macroeconomic Policies and their impact on Poverty Alleviation in Pakistan. Pakistan Development Review, Vol. 36,No.1 . 
Khattak, S. G. (2001). Women, Work and Empowerment, Working Paper No. 4. Karachi: PILER \& SDPI.

Khattak, S. G., \& Sayeed, A. (2000). Subcontract Women Workers in the World Economy: The Case of Pakistan. Islamabad: SDPI.

Kingsbury, D. (2008). Globalization and Development. In D. Kingsbury, International Development: Issues and Challenges. England: Palgrave.

Koggel, C. M. (2003). Globalization and Women's Paid Work: Expanding Freedom. Feminist Economics, 9( 2-3), 163-183.

MHCHD/UNDP. (1999). A Profile of Poverty in Pakistan. Islamabad.

Mies, M. (1998). Patriarchy and Accumulation on a World Scale: Women in the International Division of Labour. London: Zed Books.

Momsen, J. H. (2004). Gender and Development. London: Routledge.

Sayeed, A. (2001). Structural Adjustment and Its Impact on Women, Working Paper No.1. Karachi: PILER \& SDPI.

SDPI. (2008). Pakistan: Country Gender Profile. Retrieved Septemebr 12, 2010, from http://www.jica.go.jp/activities/issues/gender/pdf/e08pak.pdf

Stiglitz, J. (2002). Globalization and Its Discontents. Allen Lane: London.

Zaidi, A. A. (1999). Issues in Pakistan Economy. Karachi: Oxford.

Shagufta Nasreen is Co-operative Teacher in the Centre of Excellence for Women's Studies, University of Karachi.

Dr. Nasreen Aslam Shah is Professor in the Department of Social Work \& Director of the Centre of Excellence for Women's Studies, University of Karachi. 